JOTE Volume 2 Nomor 1 Tahun 2020 Halaman 256-261 JOURNAL ON TEACHER EDUCATION

Research \& Learning in Faculty of Education

\title{
Meningkatkan Perkembangan Kognitif Anak Melalui Bermain Bowling Aritmatika Pada Anak Usia 4-5 Tahun Kelompok A TK An- Nur Ujung Padang Kampar Utara
}

\author{
Putri Rahayu', Yusnira², Melvi Lesmana Alim \\ S1 PG-PAUD, Fakultas IImu Pendidikan, Universitas Pahlawan Tuanku \\ Tambusai \\ putrirahayu310794@gmail.com
}

\begin{abstract}
Abstrak
Penelitian ini di latar belakangi oleh masih rendahnya perkembangan kognitif di TK An-Nur Ujung Padang Kampar Utara. Penelitian ini bertujuan untuk mengetahui bagaimana meningkatkan perkembangan kognitif melalui kegiatan bermain bowling aritmatika pada anak usia 4-5 tahun TK An-Nur Ujung Padang Kampar Utara. Jenis penelitian ini adalah penelitian tindakan kelas dan jumlah anak sebanyak 15 orang anak yang terdiri dari 8 orang anak laki-laki dan 7 orang anak perempuan. Secara umum perkembangan kognitif belum berkembang. Sesudah mulai bermain bowling aritmatika pada siklus I dan II berkriteria baik yang artinya secara klasikal atau secara umum perkembangan kognitif sudah berkembang sangat baik. Dalam pengujian hipotesis dapat dilihat peningkatan yang diperoleh dari sebelum dilakukan tindakan ke siklus I peningkatan sebesar $32,8 \%$. Sedangkan peningkatan perkembangankognitif dari siklus I dan II sebesar $48,8 \%$ dan secara keseluruhan peningkatan perkembangan kognitif dari siklus I ke siklus II sebesar $97,8 \%$.
\end{abstract}

Kata kunci: Bermain Bowling Aritmatika, Perkembangan Kognitif

\begin{abstract}
This research was motivated by the low cognitive development in TK An-Nur Ujung Padang Kampar Utara. This study aims to determine how to improve cognitive development through arithmetic bowling activities in children aged 4-5 years at An-Nur Kindergarten Ujung Padang Kampar Utara. This type of research is a classroom action research and the number of children is 15 children consisting of 8 boys and 7 girls. In general, cognitive development has not yet developed. After starting to play bowling arithmetic in cycles I and II, the criteria were good, which means that in general terms, cognitive development had developed very well. In testing the hypothesis, it can be seen that the increase obtained from before the action to cycle I increased by $32.8 \%$. While the increase in cognitive development from cycle I and II was $48.8 \%$ and overall the increase in cognitive development from cycle I to cycle II was $97.8 \%$.
\end{abstract}

Keywords: Arithmetic Bowling Play, Cognitive Development 


\section{PENDAHULUAN}

Kemampuan kognitif merupakan salah satu dari enam aspek perkembangan pada anak usia dini. Dimana ketika anak mengalami mengenal atau mempunyai pengalaman tentang kasar-halus, rasa asam, manis, dan asin. la pun belajar perbedaan kata bahasa dan komunikasi timbal balik. Anak mempunyai semua proses motorik, bahasa, dan sosial emosional.

Kemampuan kognitif pada anak kelompok A merupakan kemampuan yang sangat penting dalam kehidupan sehari-hari. Pembelajaran kemampuan kognitif khususnya dalam kegiatan mengenal angka harus mendapat perhatian khusus dari guru dan pendidik. Pada pembelajaran yang dilakukan di beberapa sekolah saat ini, kegiatan mengenal angka dengan berbagai media bermain bowling aritmatika baru dikenalkan pada anak. Angka adalah suatu simbolyang di gunakan untuk melambangkan suatu nilai bilangan. Menurut Tadkirotun (2016) angka atau bilangan adalah lambang atau symbol yang merupakan suatu objek yang terdiri dari angka-angka.sebagai contoh bilangan 10, dapat di tulis dengan dua buah angka(double digits) yaitu angka 1 dan angka 10).bilangan banyak ditemui dalam kehidupan sehari-hari. Namun demikian,bilangan yang di temui anak-anak sebenarnya memiliki arti yang berbeda-beda.seperti yang di kemukakan oleh Fatimah (2016) anak-anak akan belajar membedakan arti bilangan berdasarkan penggunaan yaitu:

1. Bilangan cardinal menunjukkan kuantitas atau besaran benda dalam sebuah kelompok.

2. Bilangan ordinal digunakan untuk menandai urutan dari sebuah benda,

3. Bilangan nominal digunakan untuk member nama benda, bilangan memiliki beberapa bentuk/tampilan(represenstasi)yang saling berkaitan di antaranya benda nyata, model mainan, ucapan, symbol (angka atau kata).

Bowling adalah cabang olah raga yang berupa permainan yang cara bermainnya dengan menggelindingkan bola khusus untuk merobohkan sejumlah gada/pin yang berderet, kemudian dapat tertata secara otomatis.Bowling (bola menggelinding) adalah olaraga di dalam ruangan yang dilakukan dengan cara menggelindingkan bola khusus pada sebuah jalur untuk merobohkan pin (gada) yang berderet-deret (dalam ensiklopedia, 2005).

Permainan Bowling aritmatika adalah gabungan dari kata permainan Bowling dan angka. Kata permainan berasal dari kata "main". Menurut Hildebrand (2017) bermain berarti berlatih, mengekplorasi, merekayasa, mengulang latihan apapun yang dapat di lakukan untuk mentransformasi secara imajinatif hal-hal yang sama dengan dunia orang dewasa".

Kemampuan anak usia 4-5 tahun kelompok A TK An-NUR masih pada rentang Belum Berkembang (BB) sebesar 53,3\%. Hal ini disebabkan masih terbatas dalam penggunaan media yang digunakan oleh guru pada saat proses belajar mengajar berlangsung, sebagian besar kegiatan mengenal angka menggunakan majalah, buku tulis, papan tulis, dan jarang menggunakan APE (Alat Permainan Edukatif). Ketika mengunakan buku, anak diminta untuk menuliskan angka 1,2,3, dan seterusnya didalam kotak-kotak besar yang terdapat pada buku itu. Misalnya, pada kotak baris pertma guru memberikan contoh menuliskan angka 1. Identifikasi masalah Anak masih rendah dalam mengenal angka. Anak masih bingung dan masih belum tepat membedakan angka.Metode yang diberikan guru belum mampu menarik minat anak dalam mengenal angka. Masih terbatas dalam penggunaan media pembelajaran dalam mengenal angka. 
Rumusan masalah Bagaimanakah perkembangan kemampuan kognitif anak melalui kegiatan bermain bowling aritmatika di TK An-Nur Ujung Padang Kecamatan Kampar Utara

Tujuan Umum untuk mengetahui peningkatan perkembangan Kognitif Anak Melalui Bermain Bowling aritmatika Pada Anak Uaia 4-5 Tahun Kelompok A TK An-Nur Ujung Paadang Kampar Utara.

Berdasarkan uraian diatas, maka peneliti ingin melakukan penilitian dengan judul "Meningkatkan perkembangan kognitif anak melalui bermain bowling aritmatika pada anak usia 4-5 tahun kelompok A TK An-Nur Ujung Padang Kampar Utara"

\section{METODE}

Penelitian tindakan kelas ini rencananya akan dilaksanakan di Tk An-Nur Desa Ujung Padang melalui permainan bowling aritmatika. Penenlitian ini dilaksanakan pada pertengahan semester II tahun ajaran 2019/2020. Penentuan Waktu penelitian mengacu pada kalender akademik sekolah, karena PTK memerlukan beberapa siklus yang membutuhkan proses belajar mengajar yang efektif di kelas. PTK ini direncanakan akan dilaksanakan melalui 2 siklus untuk melihat peningkatan hasil belajar dan aktifitas anak dalam mengikuti proses pembelajaran mengenal angka di sekolah melalui permainan bowling aritmatika.

\section{PEMBAHASAN}

\section{Pratindakan dan Siklus I}

Berdasarkan hasil penelitian yang telah dilakukan dapat diketahui yang belum berkembang pada pratindakan 8 orang anak $(53,3 \%)$, sedangkan pada siklus I ada 2 orang anak (13,3\%). Dengan terjadinya penurunan persentase tersebut disebabkan karena anak telah mampu mengenal angka meskipun dengan bimbingan. Penilaian anak dalam kategori mulai berkembang pada pratindakan berjumlah 4 orang anak $(26,7 \%)$, sedangkan pada siklus I berjumlah 10 orang anak $(66,7 \%)$ hal ini disebebakan anak telah bersemangat dalam mengenal angka meskipun anak masih di ingatkan.

Dari hasil penelitian dan penjelasan data tersebut, mengindikasikan bahwa pemberian perlakuan perlakuan bermain bowling aritmatika kepada anak menunjukkan respon yang positif terhadap perkembangan kognitif anak usia 4-5 tahun di TK An-Nur Kampar Utara. Keberhasilan lain yang di dapat selain berdasarkan hasil yang telah di dapat yaitu melalui catatan lapangan.

Bermain merupakan suatu kegiatan yang menyenangkan bagi anak. Bermain juga membantu anak mengenal dirinya, dengan siapa dia hidup, serta lingkungan tempat dia hidup. Melalui bermain anak memperoleh kesempatan berkreasi, bereksplorasi, menemukan dan mengekspersikan perasaannya. Salah satu permainan tersebut adalah dengan menerapkan kegiatan bermain bowling aritmatika sebagai perkembangan kognitif anak.

Dengan kegiatan bermain bowling aritmatika di harapkan akan mengembangkan kognitif anak kelompok A TK An-Nur Ujung Padang Kampar Utara dengan baik.

Berdasarkan hasil penelitian dan pembahasan dapat di buktikan bahwa hipotesis yang mengatakan "terdapat peningkatan perkembangan kognitif anak usia 4-5 tahun melalui bermain bowling aritmatika di A TK An-Nur Ujung Padang Kampar" di terima. 
Penilaian anak dalam kategori berkembang sesuai harapan pada pratindakan berjumlah 3 orang anak (20\%), sedangkan pada siklus I berjumlah 4 orang anak (26,7\%). Pada pratindakan dan siklus I ini tidak terjadi peningkatan.

\section{Siklus I dan Siklus II}

Hasil penelitian siklus I dan siklus II menunjukkan bahwa adanya peningkatan perkembangan kognitif anak melalui bermain bowling aritmatika pada kelompok A TK An-Nur Ujung Padang Kampar Utara. Berdasarkan hasil penelitian yang dilakukan pada siklus I penilaian anak dalam kategori belum berkembang terdapat 2 orang anak sedang kan pada siklus II sudah tidak ada. Penilaian anak dalam kategori mulai berkembang pada siklus I berjumlah 9 orang anak $(60 \%)$, sedangkan pada siklus II berjumlah 2 orang anak $(13,3 \%)$. Hal ini disebabkan karena perkembangan anak dalam mengenal angka sudah mulai lebih baik. Penilaian anak dalam kategori berkembang sesuai harapan pada siklus I berjumlah 4 orang anak (26,7\%). Hal ini disebabkan telah mampu mengenal mendeskripsikan angka yang telah dikenalkan kepada anak selama bermain bermain bowling aritmatika.

Berikut ini persentase kemampuan mengenal angka melalui bermain bowling aritmatika di sekolah mulai tahap pratindakan sampai siklus II :

Tabel Persentase Hasil Penilaian Anak

\begin{tabular}{|c|c|c|c|c|c|c|c|c|}
\hline \multirow[t]{2}{*}{ Tahap } & \multicolumn{2}{|c|}{\begin{tabular}{l}
\multicolumn{1}{c}{ Belum } \\
Berkemban \\
$\mathrm{g}$
\end{tabular}} & \multicolumn{2}{|c|}{$\begin{array}{l}\quad \text { Mulai } \\
\text { Berkemban } \\
\mathrm{g}\end{array}$} & \multicolumn{2}{|c|}{$\begin{array}{l}\text { Berkembang } \\
\text { Sesuai } \\
\text { Harapan }\end{array}$} & \multicolumn{2}{|c|}{$\begin{array}{l}\text { Berkemban } \\
\text { g Sangat } \\
\text { Baik }\end{array}$} \\
\hline & $\mathrm{F}$ & $\%$ & $F$ & $\%$ & $\mathrm{~F}$ & $\%$ & $\mathrm{~F}$ & $\%$ \\
\hline Pratindakan & 8 & 53,3 & 4,0 & 26,7 & 3,0 & 20,0 & 0,0 & 0,0 \\
\hline Siklus I & 2 & 13,3 & 9 & 60,0 & 4 & 26,7 & 0,0 & 0,0 \\
\hline Siklus II & 0 & 0 & 2 & 13,3 & 10 & 66,7 & 3 & 20,0 \\
\hline
\end{tabular}

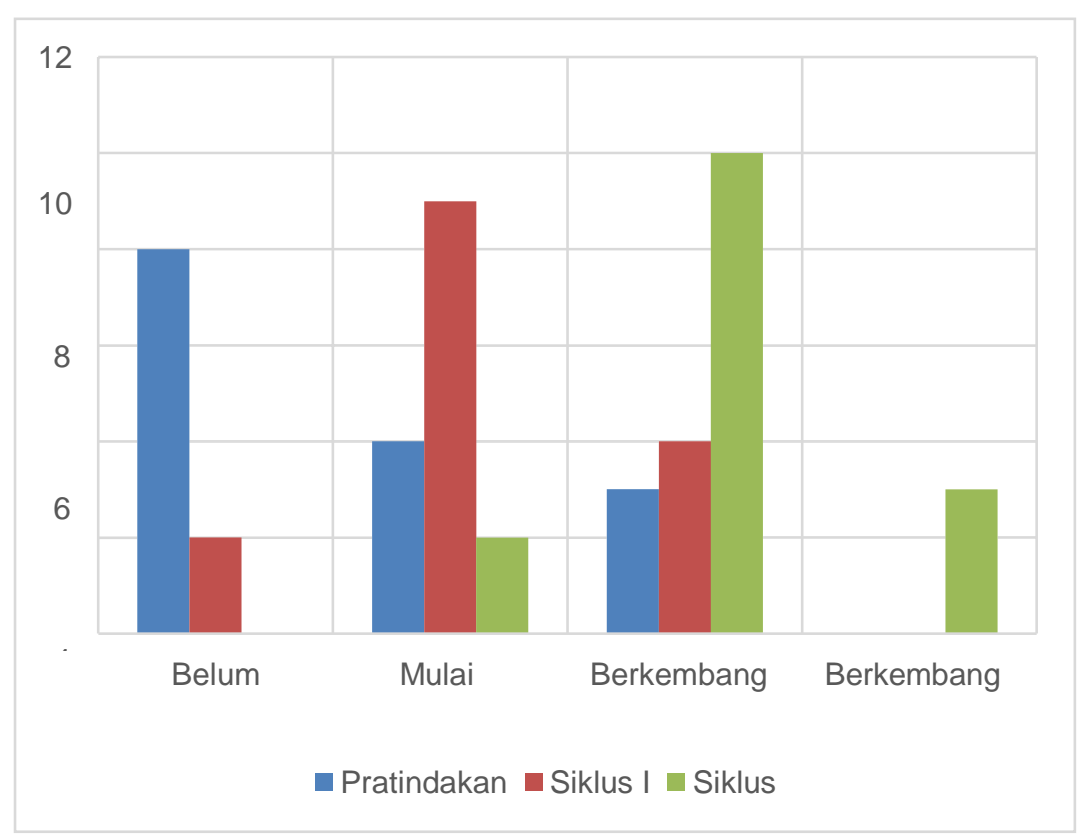

Gambar Diagram Perbandingan Pratindakan, Siklus I dan Siklus II

Setelah melihat hasil data kemampuan anak kelompok A TK An-Nur Ujung Padang Kampar Utara dalam perkembangan kognitif anak melalui bermain bowling aritmatika dapat meningkatkan kemampuan mengenal angka. Hal ini dapat dilihat dalam meningkatnya grafik persentase kemampuan mengenal 
angka pada anak usia $4-5$ tahun setelah melakukan kegiatan bermain bowling aritmatika

Hasil observasi dan penelitian pada siklus I terlihat anak lebih menyukai kegiatan pembelajaran dan mengikutinya dengan antusias yang lebih tinggi. Kegiatan pembelajaran yang di gunakan adalah metode bermain dengan media bowling aritmatika yang tentunya aman bagi anak. Metode pembelajaran ini sangat mudah dilakukan oleh anak usia $4-5$ tahun, dan kegiatan bermain ini sangat menyenangkan bagi anak.

Pada siklus II, anak menjadi antusias dan terlibat aktif dalam mengenal angka melalui bermain dengan media bowling aritmatika. Hal ini dikarenakan dengan pemberian reward kepada anak yang mau melakukan. Dengan melakukan permainan ini anak semakin bersemangat untuk belajar, karena pada dasarnya anak sangat menyukai praktek dari pada teori. Oleh karena itu, kemampuan mengenal angka pada anak kelompok A TK An-Nur Ujung Padang Kecamatan Kampar Utara sudah meningkat.

\section{KESIMPULAN}

Berdasarkan hasil penelitian dan pembahasan, maka dapat disimpulkan bahwa perkembangan kognitif anak melalui bermain bowling aritmatika pada anak kelompok A TK An-Nur Ujung Padang Kecamatan Kampar Utara, anak mengetahui peningkatan perkembangan kognitif anak melalui metode pembelajaran dilakukan dengan cara bermain bowling aritmatika. Perkembangan kognitif anak dalam mengenal angka dapat dilihat adanya peningkatan persentase dari tahap pratindakan dan setelah dilakukan tindakan.

Hasil observasi pada tahap pratindakan, anak yang berkembang sesuai harapan 3 orang anak (20\%). Kemampuan anak pada siklus I yang berkembang sesuai harapan yaitu 4 orang anak $(26,7 \%)$. Pada siklus II kemampuan anak yang berkembang sesuai harapan berjumlah 10 orang anak $(66,7 \%)$ dan pada siklus II ini kemampuan anak yang berkembang sangat baik memcapai 3 orang anak (20\%) dari jumlah keseluruah anak yaitu 15 orang anak.

Adapun faktor-faktor yang mempengaruhi peningkatan perkembangan kognitif dalam mengenal angka pada anak kelompok $\mathrm{A}$ adalah metode pembelajaran yang digunakan dapat membuat anak lebih bersemangat mengikuti proses pembelajaran. Media yang digunakan bagi anak, sehingga anak lebih tertarik untuk bermain langsung dengan menggunakan media tersebut. Kegiatan bermain yang melibatkan anak dalam kegiatan pembelajaran mampu membantun anak mengenal angka.

\section{DAFTAR PUSTAKA}

Apriani,A(2010).Penerapan Permainan Bowling Adaptif dalam Meningkatkan Bilangan 1-10 padaAnak TK. Bandung: B Prima Bakti.

Aqib,dkk. (2018). Teoridan Aplikasi Penelitian Tindakan kelas.

Yogyakarta:Deepublish

ArikuntoSuharsimi,dkk. (2010).Penelitian Tindakan Kelas. Jakarta: Pt. Bumi Aksara 
Arsyad. (2016). Media Pembelajara. Jakarta : PT. Raja grafindo Persada Djamarah. (2016). Strategi Belajar Mengajar. Jakarta : Rineka Cipta. Fatimah Ibda. (2013). Perkembangan Kognitif : Teori Jean Piaget.Vol 3 no 1

Hartati, S. (2015). Perkembangan Belajar Pada Anak Usia Dini. Jakarta : Depdiknas.

Kusumah, dkk.(2010). Mengenal Penelitian Tindakan Kelas. Jakarta: PT Indeks

Margono,s.(2010).Metodologi Penelitian Pendidikan. Jakarta:PT.RinekaCipta

Mulyasa. (2012). Manajemen Paud. Bandung : PT. Remaja

Rosdalarya Nurani. (2012). Metode Pengembangan Kognitif. Jakarta : PT iIndeks

Pratiwi , Wiwik.(2010). Konsep Bermain pada Anak Usia Dini

Rahmani,Milkanda.(2014). Buku Super Lengkap Olaraga.Jakarta: DuniaCerdas

Satrock J.W.(2011). Perkembangan Anak .Jakarta: PT Gelora

Aksara Pratama Sriningsih, N. (2017). Pembelajaran Matematika Terpadu untuk Anak Usia Dini. Bandung : Pustaka Sebelas

Sugiyono.(2014). Metode Penelitian Pendidikan. Bandung: Alfabeta

Sumarni.S. (2012).Metodologi Penelitian Pendidikan. Yogyakarta: InsanMadani

Sujiono,YulianiNuraini. (2012). Konsep Dasar Pendidikan Anak Usia Dini. Jakarta: Indeks

Susanto.A.(2011).PerkembanganAnakUsiaDiniPengantardalamberbagaiAspek. Jakarta : KencanaPrenada Group

Trianto.(2010). Desain Pengembangan Tematikbagi Anak Usia Dini TK/RA dan Anak kelas awal SD/MI. Jakarta : KencanaPrenada Media Group

Trihaso,Agung.(2013). Permainan Kreatif dan Edukatif untuk Anak Usia Dini. 